\title{
FROM COLLEGE TO UNIVERSITY: MOHAWK COLLEGE - McMASTER UNIVERSITY PARTNERSHIP, A SEAMLESS PATHWAY
}

\author{
Michael Piczak \\ McMaster University \\ B.Tech. Management Program Chair \\ Hamilton, Ontario, Canada \\ piczakm@mcmaster.ca
}

\author{
Dr. Nafia Al-Mutawaly \\ Mohawk College / McMaster University \\ B.Tech. Energy Program Chair \\ Hamilton, Ontario, Canada \\ almutan@mcmaster.ca
}

\begin{abstract}
In the mid 1960s, Ontario education policymakers recognized the need for an engineering trained individual to fill the gap between high school and university graduates, namely, an engineering technologist. This gap was filled by consolidating existing institutes of technology and creating the Ontario community college system in 1967. However, clear pathways for students to progress from an Ontario college diploma program onto a university bachelor's degree were extremely limited. In 1997, Mohawk College and McMaster University created a bachelor of technology degree partnership to offer students such an option.
\end{abstract}

This paper will discuss the unique aspects of the collaboration between Mohawk College and McMaster University, with a main focus on the inter-institutional synergies which drive the partnership's success including: shared facilities and faculty, interdisciplinary co-op placements and joint research programs.

Keywords: B.Tech., Post-graduate pathways, University / College Partnership

\section{BACKGROUND}

In 2005, former Ontario Premier Bob Rae called for more post secondary collaboration to limit the perceived 'empire of silos' forming at the institutional level [1]. Dating back to 1997, the bachelor of technology degree partnership between McMaster University and Mohawk College in Hamilton was among the first to offer such a technology degree, where 30 part time students represented the inaugural class. Today, this Yves Landry Award winning degree [2] completion program provides a channel to P.Eng., M.Eng., M.A.Sc., MBA and Ph.D. degrees. While countless colleges have followed suit, the Mohawk-McMaster partnership stands unique as a model of inter-institutional collaboration for students whose career aspirations demand scholastic options. As this collaboration evolves and matures, the various program streams provide options for newly landed immigrants to gain exposure in Canadian engineering and management practices, mature students to expand their educational foundations and college graduates to realize their full potential.

College engineering technology graduates have traditionally been expected to successfully write approximately 17 gap examinations, offered by the Professional Engineers of Ontario (PEO), to obtain standing as a professional engineer. In the mid 1970s, Ryerson Polytechnic promoted a bachelor of technology (B.Tech.) degree program, which represented one of the few avenues for college graduates to qualify for a professional engineering designation, without the need for exhaustive testing. By the mid 1990s, the chair of McMaster University's mechanical engineering program (Dr. M. Elbestawi) identified an industry need whereby individuals could pursue an engineering education during the evening while simultaneously maintaining daytime employment. This degree completion program (DCP) grew steadily until 2006 when additional degree completion programming streams (computer studies, civil/ infrastructure and energy engineering) were introduced in an evening school format. In 2007, three Four Year Integrated daytime streams were introduced by B.Tech. (biotechnology, automotive vehicle technology, and process automation). Today, enrollment levels stand at 450 students for DCP and 650 students for the Four Year degree programs. Both programs are largely delivered at and administered through McMaster University. A commitment from the Ontario Government in 2008 for $\$ 16.5 \mathrm{M}$ was awarded to ensure the continued development of the B.Tech. partnership program [3].

\section{B.TECH. vS. B.ENG}

B.Tech. was originally positioned between a college engineering technology diploma and a bachelor of engineering degree. In the minds of prospective students and employers, this periodically creates confusion. Table 
1 attempts to clarify the distinction between the two qualifications.

\begin{tabular}{|l|l|l|}
\hline & \multicolumn{1}{|c|}{$\begin{array}{c}\text { Bachelor of } \\
\text { Technology }\end{array}$} & \multicolumn{1}{c|}{$\begin{array}{c}\text { Bachelor of } \\
\text { Engineering }\end{array}$} \\
\hline $\begin{array}{l}\text { Student } \\
\text { Profile }\end{array}$ & $\begin{array}{l}\text { Students who enjoy } \\
\text { laboratory subjects and are } \\
\text { also interested in mathematics } \\
\text { and science }\end{array}$ & $\begin{array}{l}\text { Students with } \\
\text { mathematical and logical } \\
\text { strengths }\end{array}$ \\
\hline Teaching & $\begin{array}{l}\text { More hands-on } \\
\text { experimentation and } \\
\text { demonstrations during } \\
\text { lectures }\end{array}$ & $\begin{array}{l}\text { Develops understanding } \\
\text { and mathematical } \\
\text { foundations related to a } \\
\text { specific engineering } \\
\text { discipline }\end{array}$ \\
$\begin{array}{l}\text { Project work geared to } \\
\text { building specific objects or } \\
\text { systems as the end product }\end{array}$ & $\begin{array}{l}\text { Project work geared } \\
\text { towards synthesis and } \\
\text { evaluation }\end{array}$ \\
\hline $\begin{array}{l}\text { Co-op } \\
\text { Education }\end{array}$ & $\begin{array}{l}\text { Co-op mandatory - emphasis } \\
\text { on gaining hands-on } \\
\text { experience through jobs in } \\
\text { industry }\end{array}$ & $\begin{array}{l}\text { Co-op desirable but not } \\
\text { mandatory - emphasis on } \\
\text { application of } \\
\text { engineering theory }\end{array}$ \\
\hline Careers & $\begin{array}{l}\text { Primarily in "hands-on" } \\
\text { technology applications (e.g. } \\
\text { production, manufacturing, or } \\
\text { construction supervision) }\end{array}$ & $\begin{array}{l}\text { Positions in a range of } \\
\text { technical environments, } \\
\text { including design, project } \\
\text { management, policy } \\
\text { development, or business } \\
\text { and financial analysis } \\
\text { may progress to } \\
\text { primarily technical context, } \\
\text { with opportunities to progress } \\
\text { to management and } \\
\text { supervisory positions } \\
\text { with Extensive } \\
\text { supervisory } \\
\text { responsibilities }\end{array}$ \\
\hline
\end{tabular}

Table 1: B.Tech. vs. B.Eng. Comparison

Compared to a bachelor of engineering degree, B.Tech. features more practical engineering studies, math across the curriculum (rather than in multiple stand alone courses), and closer ties between lectures and real world applications as captured in courses and capstone projects.

\section{B.TECH'S UNIQUE MODEL}

A number of characteristics contribute to the unique B.Tech. model including:

- Seamless academic pathways - B.Tech. degree completion programs have been designed to provide seamless transition for college engineering technology graduates (civil, computer studies, mechanical and electrical). Incoming students are granted two years of credit and are required to complete 17 technical courses as well as 7 management courses to achieve a bachelor of technology degree, allowing B.Tech. graduates to be considered for masters level studies (Figure 1).

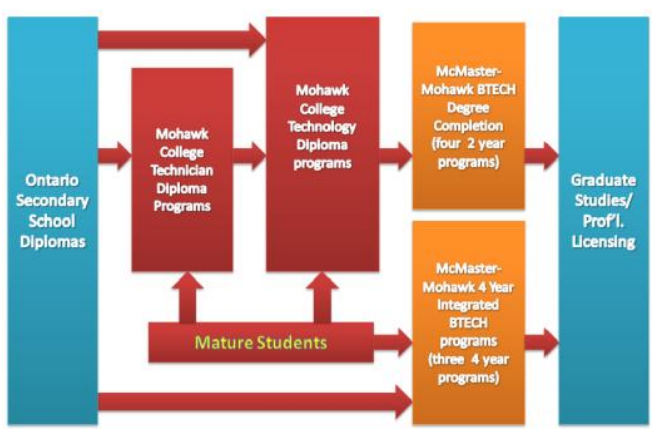

Figure 1 - B.Tech. Undergraduate Program Paths

- Industry Driven Academic Programs - B.Tech. programming streams and course content are shaped by industry representatives who volunteer to sit on program advisory committees. Such practicing engineers, technologists, managers and community leaders ensure that curricula are current and relevant as judged against industry standards and needs.

- Accessibility to Working Professionals - With few post secondary, university level, engineering, part time options available to college graduates, a pent up demand for post college engineering education was recognized. From their inception, DCP streams targeted the working professional looking to maintain knowledge currency while simultaneously improving the level of their professional credentials.

- Mandatory Co-op - Mandatory co-op represents a key feature of all B.Tech. programs. For DCP streams, prior college co-op experiences are recognized and credited where student studies continue within the same discipline. In addition, coop placements provide landed immigrants with exposure to Canadian engineering/business practices, allowing them to demonstrate previously accumulated competencies. Traditional 4 month coop terms are replaced with 8 to 16 month work placements. The extended period permits companies to better assess a candidate's long-term potential within their organization.

- Short Duration and Flexibility - DCP streams offer three intakes during a calendar year, with students' progress proceeding at a pace reflective of personal preference and circumstance. Program flexibility allows B.Tech. students to complete degrees in a relatively short time (24 months), subject to course availabilities.

- Management studies - Complementing the technical studies, seven management courses (5 core with two optional) were introduced to the B.Tech. 
programs in 2007. Management course offerings include:

- Financial Systems (core)

- Technological Entrepreneurship (core)

- Engineering Economics (core)

- Human Behaviour in Technology Settings (core)

- Management of Technical Projects (core)

- Formulating Technology Strategy

- Legal and Regulatory Issues

- Contemporary Issues in Management

- Creativity, Innovation, and Technology

- Human Resources in Technology Settings

- Lean Thinking

- Sustainability (under development)

\section{PROGRAM STRENGTHS}

Surveys and focus groups have been administered over the years to gage student reaction/attitudes to program offerings, course quality and related delivery issues. A recent (2013) comprehensive, on-line survey asked DCP students over 100 questions dealing with various aspects of the programs. The top 5 student response categories are shown in Table 2.

\begin{tabular}{|l|l|}
\hline & \multicolumn{1}{|c|}{ Degree Completion Students ( $=175)$} \\
\hline$\# 1$ & $\begin{array}{l}\text { Flexible schedule/ability to work (evening \& } \\
\text { weekend classes) }\end{array}$ \\
\hline$\# 2$ & Quality of instructors \\
\hline$\# 3$ & Industry focused blend of theory and practical \\
\hline$\# 4$ & Small class sizes \\
\hline$\# 5$ & P.Eng. pathway \\
\hline
\end{tabular}

Table 2: Survey Highlights

\section{UNIQUE ASPECTS OF THE MOHAWK- MCMASTER COLLABORATION}

Since its inception, the B.Tech. program has utilized facilities and personnel from both institutions to achieve program objectives. Rather than duplicate lab and other facilities, courses are offered in the institution possessing the necessary lab and equipment to support a given course. Courses are delivered by faculty from both institutions with hiring preference given to applicants holding masters/Ph.D. degrees and professional engineering (P.Eng.) designations.

Mohawk College has the distinction of being the first college in Canada to hold a research chair in engineering with the awarding of a substantial Natural Sciences and Engineering Research Council (NSERC) grant in 2013.
This cross appointment permits enhanced collaboration between institutions enabling faculty to work on applied research projects, solving problems for industry in the field of energy engineering. Faculty, industry, and students collaborate to publish conference and journal papers, something rather unique for college faculty who typically have substantial teaching commitments.

In addition, credit level courses have been offered to industrial partners as local companies look to upgrade competencies with in-house university level education. Diplomas are conferred to those who complete five and seven course certificate programs.

Finally, the programs are governed by jointly operated steering committees which provide continuous guidance and policy direction.

\section{LIFE AFTER B.TECH.}

B.Tech. students are provided two options upon graduation: perusing related employment or continuing their studies. Post graduation placements in related fields are very high with students assuming positions including:

- Plant Manager

- Engineering and Maintenance Manager

- Project Manager

- Senior Sales Executive

- Design Engineer

- Owner/President

Figure 2 illustrates the basic academic post graduate options.

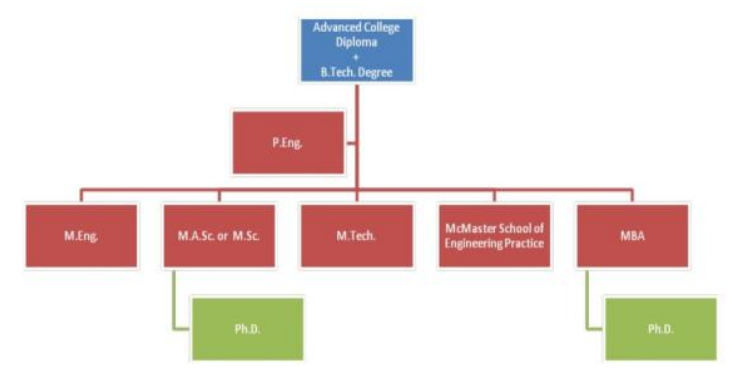

Figure 2 - B.Tech. Post-Graduate Pathways

Professional Engineer - Approximately $8 \%$ of graduates pursue professional licensure through the PEO while $5 \%$ proceed to graduate level studies in both technical and managerial fields.

Professional licensing takes on two forms for B.Tech. graduates [4]: 
1. Professional Engineering license (P.Eng.) after writing a prescribed number of gap examinations (along with the professional practice and ethics examination as well as a technical report)

2. Professional Engineering Limited License (L.L.) where such a limited license establishes boundaries around the scope of work that an individual is permitted to participate in.

Recent legislation in the Province of Ontario will necessitate that individuals undertaking work involving the application of engineering principles and knowledge will need to have one of the two designations shown above. It is expected that this will drive demand for more B.Tech. education.

M. Eng./M.A.Sc./M.Tech. - At McMaster University, B.Tech. graduates have continued studies in the School of Engineering (electrical and computer engineering, civil engineering and within the school of engineering practice). These students can pursue post graduate degrees (M.Eng., M.A.Sc. or M.Tech). in civil, aerospace, computer, bio-mechanical and traditional mechanical engineering.

MBA - B.Tech. graduates have continued to the MBA at McMaster and other universities. No credits for prior learning are extended for B.Tech. coursework (despite high grade point averages) requiring applications to complete Graduate Management Admission Tests (GMATs). Additionally, a full 20 course complement must be taken to achieve the degree.

Ph.D. - Students proceeding from M.A.Sc. programs can continue to a Ph.D. To date, three B.Tech. graduates have completed Ph.D's.

\section{CONCLUSIONS}

The Mohawk College-McMaster University Bachelor of Technology Partnership program is well into its second decade of operation. Program success can be measured in any number of ways including: number of students, number of course enrollments, percentage co-op/full time related placement, student satisfaction, faculty satisfaction and others. The B.Tech. programs have shown steady and strong growth for over 15 years, with targets now being set to double enrollments within the next few years. B.Tech. programming has broad appeal for both working professionals and high school students who are interested in practical, hands-on university education. Challenges in terms of maintaining small class sizes, attracting/retaining quality faculty/instructors and developing new programming streams remain the primary focus of B.Tech. academic leadership.

\section{Acknowledgements}

The authors of this paper wish to thank the Dean of engineering at McMaster University for the financial support which made this paper possible.

\section{References}

[1] B. Rae, "Ontario - A Leader in Learning - Report and Recommendations," Ontario Ministry of Training, Colleges and Universities, 2005.

[2] McMaster University, "McMaster-Mohawk technology program receives award," 0709 2006. [Online]. Available: http://dailynews.mcmaster.ca/article/mcmaster-mohawktechnology-program-receives-award/. [Accessed 2704 2013].

[3] McMaster University, "Premier gives \$16.5 million to McMasterMohawk BTech program," 0702 2008. [Online]. Available: http://dailynews.mcmaster.ca/article/premier-gives-16-5-millionto-mcmaster-mohawk-btech-program/. [Accessed 1504 2013].

[4] M. P. Moody Samuel Farag, Writer, P.Eng Licencing Process McMaster B.Tech. Students. [Performance]. Professional Engineers Ontario, 2013. 